\title{
ВИЗНАЧЕННЯ КАТЕГОРІї «ПРИВАТНИЙ ІНТЕРЕС» У НАЦІОНАЛЬНОМУ ЗАКОНОДАВСТВІ УКРАЇНИ
}

Кондуфорова Л. В.

\begin{abstract}
У статmі детально досліджено національне законодавство з точки зору аналізу прямого та опосередкованого закріплення у відповідних нормативно-правових актах категоріі приватний інтерес. Категорія «приватний інтерес» знайшла своє законодавче регулювання як у нормативно-правових актах публічного, так $і$ приватного права. Встановлено, що основоположними актами у сфері закріплення і регулювання приватних інтересів є Конституція України та Цивільний кодекс. Опосередковано регулювання приватних інтересів здійснюється низкою інших нормативно-правових актів. Визначено, що нагальним на сьогодні $\epsilon$ детальне законодавче регулювання приватного інтересу, враховуючи відповідні міжнародні та європейські стандарти.
\end{abstract}

Ключові слова: правовий інтерес, приватний інтерес, публічний інтерес, майновий інтерес, немайновий інтерес.

В статье подробно исследовано национальное законодательство с точки зрения анализа прямого и косвенного закрепления в соответствующих нормативно-правовых актах категории частный интерес. Категория «частный интерес» нашла свое законодательное регулирование как в нормативно-правовых актах публичного, так и частного права. Установлено, что основополагающими актами в сфере закрепления и регулирования частных интересов является Конституция Украины и Гражданский кодекс. Косвенно регулирования частных интересов осуществляется рядом других нормативно-правовых актов. Onределено, что актуальным на сегодня является детальное законодательное регулирование частного интереса, учитывая соответствующие международные и европейские стандарты.

Ключевые слова: правовой интерес, частный интерес, публичный интерес, имущественный интерес, неимущественный интерес.

This article explores national legislation of direct and indirect consolidation in the relevant legal acts of the category of private interest. It is established that the category of "private interest" has found its legislative regulation in both the legal acts of public and private law. It is established that the basic acts in the sphere of securing and regulating private interests are the Constitution of Ukraine and the Civil Code. Indirect regulation of private interests is carried out by a number of other regulatory acts. It is determined that detailed regulation of private interest, taking into account relevant international and European standards, is urgent today.

The author finds out that the separation of the right to public and private and the question of the category of private and public interests has always been the limit in the center of attention of scientists. The legal doctrine highlights a wide variety of views regarding the normative consolidation of private interests in national legislation. Some scholars believe that private interests can only be consolidated within the framework of private law. Other scholars support the position that regulatory coverage

Кондуфорова Л. В., 2019 of private interests is possible both within the framework of private and public law.

The article established that private interest is directly enshrined in only one regulatory act: the Law of Ukraine "On the Prevention of Corruption". The provision on the private interest of an individual can be traced when analyzing the norms of the Constitution of Ukraine, the Civil Code of Ukraine, the Law of Ukraine "On Information", the Law of Ukraine "On Access to Public Information", and the Law of Ukraine "On the Protection of Personal Data".

The author identifies the shortcomings of the current legislation of Ukraine and suggests ways to solve existing problems associated with the definition of private interest in the national legislation of Ukraine.

Key words: legal interest, private interest, public interest, property interest, non-property interest.

Постановка проблеми та іï актуальність. Після того, як Україна стала незалежною, в державі постало нагальне питання реформування національного законодавства, відповідно до постулатів демократичної, правової та соціальної держави. Проголошення людини найвищою соціальною цінністю опосередковувало необхідність закріплення в національному законодавстві приватного інтересу, як інтересу конкретного індивіда, котрий має враховуватися при державотворенні та правовому регулюванні в цілому. У свою чергу, сьогодення характеризується активними нормотворчими процесами, що зачіпає правове регулювання базових сфер життя. На сучасному етапі $\epsilon$ прийняті або викладені в новій редакції численні нормативно-правові акти, що зачіпають економічний, соціальний, освітній, фінансовий та інші пласти національного законодавства. Така ситуація прямо та опосередковано пов'язана із підписанням Угоди про асоціацію між Україною, з однієї сторони, та Європейським Союзом, Європейським співтовариством з атомної енергії і їхніми державами-членами, з іншої сторони [1]. Осучаснення національного законодавства, його проєвропейський вектор безумовно позитивно впливають на закріплення постулатів про приватний інтерес у національному законодавстві, але в силу браку відповідних наукових доробок у цій сфері обрана проблематика $\epsilon$ вкрай актуальною.

Аналіз останніх досліджень і публікацій. Проблематика приватного інтересу, зокрема і відображення його у національному законодавстві, було розглянуто у напрацюваннях таких вітчизняних науковців, як Р. Калюжний, О. Підопригора, С. Погребняк, П. Рабінович, В. Селіванов, М. Самбор, О. Харитонова, Є. Харитонов та інші. Проте слід визнати, що вищеперераховані вчені розглядали обрану проблематику лише фрагментарно, не проводячи ґрунтовних наукових пошуків та не аналізуючи відповідне законодавство на належному рівні. Саме тому, на нашу думку, обрана проблематика $\epsilon$ актуальною та потребує детального вивчення. 
Мета статті. 3 огляду на це мета дослідження полягає в тому, щоб детально дослідити національне законодавство з точки зору аналізу прямого та опосередкованого закріплення у відповідних нормативно-правових актах категорії «приватний інтерес».

Виклад основного матеріалу. Перш за все зазначимо, що інтереси, в тому числі приватні, сприяють виникненню, зміні та розвитку суспільних відносин у базових сферах суспільного життя, зокрема у сферах економіки, освіти, фінансів, соціального сектору, тощо. Варто відзначити, що ще стародавні мислителі, зокрема Платон, у своїй праці «Закони» аналізував положення про зіставлення приватних (особистих) та публічних (державних) інтересів. При цьому філософ віддавав перевагу саме публічним інтересам, адже вони, на думку Платона, виступали спільністю приватних інтересів, що опосередковувало розвиток держави [2]. На сьогодні погляди щодо співвідношення публічних та приватних інтересів змінилися, так науковці відходять від радикальних поглядів на те, що має простежуватися чітке переважання одних інтересів над іншими, до їхнього гармонійного співвідношення між собою. Говорячи про приватні інтереси та їхн закріплення в національному законодавстві, слід звернутися до думок вченої Харитонової О., котра визначає, що інтерес набуває приватноправового характеру виключно в тому разі, якщо він буде закріпленим у нормах приватного права [3]. Таким чином, приватноправовий інтерес закріплюється приватним правом, яке, у свою чергу, за змістом визначається приватним інтересом. На наше переконання, $\epsilon$ недоцільним говорити про те, що приватний інтерес $\epsilon$ закріпленим лише в нормах приватного права. При цьому слід визнати, що критерій інтересу $є$ базовим для здійснення поділу права на приватне та публічне, проте не єдиним критерієм відповідного поділу. Таким чином, приватні інтереси можуть та мають бути закріпленими й у положеннях публічного права, і в положеннях приватного права, адже сам поділ права на публічне та приватне в останні роки проголошується умовним поділом, адже як у публічну царину спостерігаються вкраплення приватної, так й у приватну спостерігаються вкраплення публічної.

Переходячи до висвітлення обраної проблематики по суті, зазначимо, що національне законодавство містить лише одну норму, яка прямо визначає категорію «приватний інтерес». Відтак Закон України «Про запобігання корупції» у ст. 1 надає визначення даній категорії та встановлює, що приватний інтерес - це будьякий майновий чи немайновий інтерес особи, в тому числі зумовлений особистими, сімейними, дружніми чи іншими позаслужбовими стосунками з фізичними чи юридичними особами, у тому числі ті, що виникають у зв'язку з членством або діяльністю у громадських, політичних, релігійних чи інших організаціях [4]. Аналізуючи положення правової доктрини та наводячи власні міркування, потрібно визнати, що запропоноване законодавцем розуміння категорії приватний інтерес $\epsilon$ доцільним, проте не може розглядатися, як єдино вірне та стале, але враховуючи те, що визначення даної категорії не $\epsilon$ метою та власне проблематикою даного дослідження, сконцентруємо увагу саме на нормативному закріплені в національному законодавстві відповідної правової категорії.
Перш за все, встановимо, що правова категорія приватний інтерес має пронизувати своєю суттю все національне законодавство, адже це буде відповідати концепту людиноцентричності, що $\epsilon$ визначеним Конституцією України. Слід зазначити, що окрім Закону України «Про запобігання корупції» ще 3 аналізу цілого ряду актів національного законодавства можна опосередковано дослідити та проаналізувати цю категорію. До таких нормативно-правових актів, зокрема належить Конституція України, Цивільний Кодекс України, Закон України «Про захист персональних даних», Закон України «Про інформацію», Закону України «Про доступ до публічної інформації». Тож нижче пропонуємо детально проаналізувати відповідні нормативно-правові акти, крізь призму закріплення категорії приватний інтерес у них.

Опосередковано постулати приватного інтересу можна простежити й у ст. 41 Конституції України, яка визначає, що «кожен має право володіти, користуватися й розпоряджатися своєю власністю, результатами своєї інтелектуальної, творчої діяльності. Право приватної власності набувається в порядку, визначеному законом. Громадяни для задоволення своїх потреб можуть користуватися об'єктами права державної та комунальної власності відповідно до закону. Ніхто не може бути протиправно позбавлений права власності. Право приватної власності $\epsilon$ непорушним<...>». Аналізуючи відповідну норму, потрібно встановити, що в даному разі йде мова про приватний майновий інтерес особи, пов'язаний із можливістю мати на титулі власності найрізноманітніші об'єкти, крім тих, що прямо визначені законодавством. Слід визнати, що сама категорія власності посідає чільне місце не лише в суспільному житті, але й у свідомості кожної особи. При цьому приватний інтерес доволі тісно межує із публічним інтересом, проте все ж переважає над ним. Положення про непорушність права власності та разом з тим і приватний майновий інтерес особи $€$ закріпленим не лише в Конституції України, але і $\epsilon$ деталізованим іншими законодавчими актами, як національними так і міжнародними. Зокрема ст. 1 Першого Протоколу до Європейської конвенції про захист прав людини й основоположних свобод, що була ратифікованою Україною 11 вересня 1997 року, передбачає, що «кожна фізична або юридична особа має право мирно володіти своїм майном. Ніхто не може бути позбавлений свого майна інакше як в інтересах суспільства і на умовах, передбачених законом або загальними принципами міжнародного права...» [6].

У такий спосіб, норми Конституції опосередковано закріплюють положення як про особистий немайновий, так і про майновий приватний інтерес індивідів. При цьому відповідні норми Конституції України $\epsilon$ базовими для формування профільного національного законодавства та закріплення категорії приватний інтерес у ньому.

у межах Цивільного кодексу можна простежити низку норм, які $є$ спрямованими на охорону приватного інтересу індивіда. Варто зазначити, що цілком виправданим видається те, що норми Цивільного кодексу охороняють більшою мірою саме приватний інтерес та закріплюють пріоритет останнього над публічним, адже саме цивільне право $є$ основною серед інших приватних галузей права. Як логічне продовження проаналізованих вище норм Конституції України, які стосува- 
лися охорони сімейного та особистого життя, а також права власності, сконцентруємо увагу на аналогічних нормах Цивільного кодексу. Так, доцільним видається звернутися до статей 277- 279, 301-306, 319-321, вищезазначеного нормативно-правового акту [7].

Занашимпереконанням, доцільнимта обґрунтованим видається також звернути увагу на ст. 304-306 Цивільного кодексу, адже в них висвітлено приватний інтерес індивіда в царині убезпечення конфіденційності його особистих паперів, а отже особистого, сімейного життя. Ст. 304 визначає, що фізична особа, якій належать особисті папери, може усно або в письмовій формі розпорядитися ними, в тому числі й на випадок своєї смерті. 3 огляду на дану правову норму вбачається, що лише конкретний суб'єкт може за власним бажанням розголошувати чи не розголошувати дані про своє особисте, сімейне життя на загал.

3 огляду на дослідження та аналіз вищеперерахованих норм Цивільного кодексу, видається простежити опосередковане нормативне закріплення категорії приватний інтерес, як немайновій так і в майновій сферах життя особи.

У межах Закону України «Про захист персональних даних» $€$ доцільним сконцентрувати увагу на ч. 2 ст. 14, в якій ідеться про те, що поширення персональних даних без згоди суб'єкта персональних даних або уповноваженої ним особи дозволяється у випадках, визначених законом, і лише (якщо це необхідно) в інтересах національної безпеки, економічного добробуту та прав людини [8]. 3 огляду на це видається логічним визнати, що відповідна норма кореспондує із аналогічними, що закріплені Конституцією та Цивільним кодексом України, проте стосується специфічного об'єкту, а саме персональних даних особи. Відповідно до ст. 2 вищезазначеного закону персональні дані - це відомості чи сукупність відомостей про фізичну особу, яка ідентифікована або може бути конкретно ідентифікована. 3 огляду на це видається встановити, що в законодавстві $€$ неможливим навести чіткий перелік відомостей, що належить до персональних даних особи, адже залежно від ситуації вони будуть варіюватися. Отже, констатуємо, що в даному разі простежується як майновий, так і немайновий приватний інтерес індивіда.

Отож, в межах Закону України «Про захист персональних даних», опосередковано закріплюється постулат про немайновий та майновий приватний інтерес індивіда у сфері забезпечення збереження персональних даних особи від несанкціонованого втручання та їх оброблення без дозволу особи, якій вони належать.

У межах ч. 2 ст. 21 Закону України «Про інформацію» законодавець висвітлює положення про приватний немайновий інтерес особи у сфері забезпечення недоторканності конфіденційної інформації щодо неї. Через те визначається положення про те, що «конфіденційною $\epsilon$ інформація про фізичну особу, а також інформація, доступ до якої обмежено фізичною або юридичною особою, крім суб'єктів владних повноважень. Конфіденційна інформація може поширюватися за бажанням (згодою) відповідної особи у визначеному нею порядку відповідно до передбачених нею умов, а також в інших випадках, визначених законом» [9]. 3 огляду на правову норму, що була викладена вище, видається встановити, що вона кореспондує, як із аналогічними нормами Конституції, так і з нормами Цивільного кодексу України.
При цьому слідує відмітити, що підставою для визначення інформації конфіденційною $є$ бажання фізичної чи юридичної особи вважати певну інформацію про неї чи інформацію, що знаходиться в їі володінні, конфіденційною. До конфіденційної інформації про особу можна віднести: відомості про національність, освіту, сімейний стан, релігійні переконання, стан здоров'я, адреса, дата та місце народження; реєстраційний (ідентифікаційний номер платника податків) номер облікової картки фізичної особи; відомості про особисте життя громадян; відомості про місце проживання; відомості про страховий стаж; результати медичних обстежень; отримані доходи застрахованої фізичної особи, тощо.

Окрім того законодавець надає можливість особи самостійно на власний розсуд визначити, яка інформація (ії обсяг) $\epsilon$ конфіденційною щодо неї, якщо це не суперечить закону. У даному разі особа може реалізовувати особистий немайновий приватний інтерес, котрий з огляду на вищевикладене має переважати над публічним.

Слід відзначити, що аналогічні міркування були сформульованими й викладені в рішенні Конституційного Суду України від 20 січня 2012 року, в якому наголошується, що лише фізична особа, якої стосується конфіденційна інформація, має право вільно, на власний розсуд визначати порядок ознайомлення з нею інших осіб, держави та органів місцевого самоврядування, а також право на збереження ії у таємниці, відповідно до конституційного та законодавчого регулювання права особи на збирання, зберігання, використання та поширення конфіденційної інформації [10].

Отже, варто відзначити, що законодавець передбачає охорону особистого немайнового приватного інтересу суб'єкта в контексті забезпечення схоронюваності конфіденційної інформації щодо конкретної особи.

Як логічне продовження розгляду положень Закону України «Про інформацію», доцільно сконцентрувати увагу на положеннях Закону України «Про доступ до публічної інформації», зокрема на ч. 2. ст. 7. Відповідна правова норма закріплює положення про те, що розпорядники інформації, які володіють конфіденційною інформацією, можуть поширювати ії лише за згодою осіб, які обмежили доступ до інформації, а за відсутності такої згоди - лише в інтересах національної безпеки, економічного добробуту та прав людини. Отже, розпорядники інформації $\epsilon$ обмеженими в можливості розпоряджатися конфіденційною інформацією про особу, згодою особи якої стосується відповідна інформація.

Висновки. 3 огляду на все вищевикладене зробимо низку висновків. Поділ права на публічне та приватне, а разом із тим і вивчення питання про категорії приватних та публічних інтересів, завжди було в межах наукових пошуків учених. При цьому доктрина висвітлює найрізноманітніші погляди щодо нормативного закріплення приватних інтересів у національному законодавстві. Так, на думку одних науковців, приватні інтереси можуть бути закріпленими лише в межах приватного права, інші ж підтримують позицію щодо можливості нормативного висвітлення приватних інтересів як у межах приватного, так і в межах публічного права. Разом із цим варто відзначити, що приватний інтерес $\epsilon$ прямо закріпленим лише в одному нормативно-правовому акті, а саме - в Законі України «Про запобігання корупції», не дивлячись на це варто зазначити, що ана- 
лізована правова категорія своєю суттю пронизує все національне законодавство, що $є$ обумовленим існуванням демократичної, правової держави, в межах якої закріплено постулат людиноцентризму. На сьогодні положення про приватний інтерес індивіда опосередковано можна простежити крізь призму аналізу норм Конституції України, Цивільного Кодексу України, Закону України «Про інформацію», Закону України «Про доступ до публічної інформації», Закону України «Про захист персональних даних».

Варто відзначити, що національне законодавство закріпило норми як про майновий, так і про немайновий приватний інтерес особи, зокрема у сфері права власності, та інформаційній сфері, що були проаналізовані вище. При цьому слідує встановити, що на сьогодні на рівні правотворчості й правозастосування існують численні проблеми, пов'язані з відсутністю належного правового регулювання приватних інтересів як таких, про це, зокрема, неодноразово наголошував і Конституційний Суд України у власних рішеннях. Враховуючи активні процеси нормотворення та реформування національного законодавства, відповідно до європейських стандартів, дана ситуація потребує нагального вирішення на законодавчому рівні, тому що поверхневе законодавче врегулювання знецінює саму суть приватних інтересів, а разом із тим і права людини, що $є$ неприпустимим.

Отже, обрана проблематика дослідження може стати основою для подальших наукових пошуків у царині аналізу закріплення положень про приватний інтерес у національному законодавстві в найрізноманітніших сферах правового регулювання.

\section{Література}

1. Угода про асоціацію між Україною, з однієї сторони, та Європейським Союзом, Європейським співтовариством з атомної енергії і їхніми державами членами, 3 іншої сторони. URL: https://zakon.rada.gov.ua/laws/ show/984_011 (дата звернення 11.12.2019).
2. Хрестоматія з історії політичних вчень: посіб. Упоряд. автор коментарів О. Уривалкін. К.: Дакор, КНТ, 2008. $456 \mathrm{C}$.

3. Харитонова О. Поділ права на публічне та приватне: теоретичні питання. Вісник Харківського інституту регіонального управління і права. 2003. № 1. С. 45-47.

4. Про запобігання корупції: Закон України від 14.10.2014. № 1700-VII. Відомості Верховної Ради України. 2014. № 49. ст. 2056

5. Конституція України: Закон України від 28.06.1996 р. № 254к/96-ВР. Відомості Верховної Ради України. 1996. 23 лип. (№ 30). С. 141.

6. Конвенція про захист прав людини і основоположних свобод. Електронний ресурс. Режим доступу: https://zakon.rada.gov.ua/laws/show/995_004 (дата звернення 11.12.2019).

7. Цивільний кодекс України. URL: https: / / zakon.rada.gov.ua/laws/show/435-15 (дата звернення 11.12.2019).

8. Закон України «Про захист персональних даних». URL: https://zakon.rada.gov.ua/laws/show/2297-17 (дата звернення 11.12.2019).

9. Закону України «Про інформацію». URL: https://zakon.rada.gov.ua/laws/show/2657-12 (дата звернення 11.12.2019).

10. Рішення Конституційного Суду України у справі за конституційним поданням Жашківської районної ради Черкаської області щодо офіційного тлумачення положень частин першої, другої статті 32, частин другої, третьої статті 34 Конституції України: від 20.01.2012 р., № 2-pп/2012. URL: http://zakon1.rada.gov. ua/laws/show/ v002p710-12 (дата звернення 11.12.2019).

Кондуфорова Л. В., аспірант кафедри адміністративного, фінансового і банківського права Навчально-наукового інституту права імені князя Володимира Великого міжрегіональної Академії управління персоналом 